\title{
Life Cycle Assessment of Organic, BCI and Conventional Cotton: A Comparative Study of Cotton Cultivation Practices in India
}

\author{
Pragnesh Shah, Abhishek Bansal and Rajesh Kumar Singh
}

\begin{abstract}
Cotton, the most important cash crop of India plays a dominant role in its agrarian and industrial economy. In India, the area under cotton cultivation is the highest in the world and industry provides livelihood to over seven million people. However, cotton productivity in India is low and farmers rely on heavy dosage of fertilizers and insecticides/pesticides to control insects, pests, weeds and growth regulators. Organic cotton farming is the process of growing cotton without the use of synthetic pesticides and chemical fertilizers. Better Cotton Initiative (BCI), is a concept to grow cotton with judicious use of water, chemical fertilizers and pesticides, to reduce the environmental footprint of cotton farming. The objective of the study was to quantify the environmental benefits associated with the production of organic seed cotton and BCI seed cotton compared to the conventional production of seed cotton, using Life Cycle Assessment approach. The aim was also to identify hotspots across the cultivation process. The study was based on primary data collected from farming sites managed by Arvind Group under contract farming model for BCI cotton and organic cotton cultivation in the state of Maharashtra, India. When compared with the conventional cotton system, the organic and BCI cotton show considerable advantage for several impacts categories.
\end{abstract}

\section{Introduction}

Cotton is an indispensable part of today's human life and India is now the second largest producer of cotton in the world, producing around $18 \%$ of the world's cotton [1]. It has the largest area under cotton cultivation in the world (8.9 Million hectare), representing about $25 \%$ of the world area under cotton cultivation [2]. For the

\footnotetext{
P. Shah · A. Bansal

Arvind Limited, Naroda Road, Ahmedabad, Gujarat, India

R. K. Singh $(\square)$

Thinkstep Sustainability Solutions Pvt. Ltd., 421, Sahar Plaza,

Andheri (E), Mumbai, Maharashtra, India

e-mail: Rajesh.Singh@thinkstep.com

(C) The Author(s) 2018

E. Benetto et al. (eds.), Designing Sustainable Technologies,

Products and Policies, https://doi.org/10.1007/978-3-319-66981-6_8
} 
financial year 2015-16 total production of cotton was 338 hundred thousand bales (1 Indian bale $=170 \mathrm{~kg}$ ), out of which $20 \%$ was exported [1]. Environmental sustainability of cotton fibres production has gained more and more attention from both suppliers and consumers in recent years due to the associated resources consumption and pollutant emissions. There are mainly three types of cotton cultivation practices: Conventional, Organic and BCI cotton seed farming. Conventional Cotton farming is the process of growing cotton with use of insecticides, pesticides, herbicides, defoliants, fertilizers, and lot of water. Many conventional systems use rain fed water instead irrigation thus conserving surface and groundwater and also limiting the use of agricultural inputs (fertilizers, pesticides, and machinery) [3]. Organic cotton farming is done without use of synthetic pesticides and chemical fertilizers and the only additives comes in the form of manures, while soil quality is controlled by crop rotation. The impact on the environment is therefore reduced drastically, producing clean and safe cotton while creating a sustainable cycle [4]. It is best suited for small and marginal farms and Arvind Limited is working closely with the farmers of Akola in the Vidarbha region of Maharashtra to grow organic cotton; initiative has helped to improve the livelihood of the farmers by increasing their per-acre income. BCI is a concept to grow cotton with judicious use of water, chemical fertilizers and pesticides. This technique works well in fertile and irrigated regions where organic farming is not economically viable. Since 2010, Arvind as implementation partners of BCI in India have been working with over four thousand farmers in the Akola region covering over 15,815 ha of farmland. In 2014, the total production of BCI cotton was 283,000 MT on 456,000 ha. Better Cotton is produced in ten states of India and year-on-year figures for BCI Farmers, Better Cotton lint produced, and hectares under cultivation have increased [5]. Several studies based on Life Cycle Assessment (LCA) [6] have been done on the environmental footprint of cotton cultivation which includes Murugesh and Selvadass [7], Khabbaz et al. [8], Barnes [9], Cotton Incorporated [10], Textile Exchange and PE International [4], Cotton Made in Africa [3]. Conventional seed cotton fibres have greater environmental impacts compared to the organic cotton fibres [7] and irrigation has the highest contribution for both conventional and organic seed cotton fibres [7]. Field emissions and fertilizers manufacturing contribute significantly to most of the environmental impacts categories [Global Warming Potential (GWP), Ozone Depletion Potential (ODP), and Primary Energy Demand (PED)] [9]. Cotton Incorporated, a pioneer research and marketing company, has done an LCA of cotton fibres with the help of thinkstep AG (former PE International) [10]. The foreground data have been collected from three countries U.S., China, and India; representing 67\% of the world cotton fibres production. GWP and PED for $1 \mathrm{~kg}$ of cotton fibres were estimated to be $15 \mathrm{MJ}$ and $0.268 \mathrm{~kg} \mathrm{CO}_{2}$ eq. According to other literature references, cotton fibres production induces an energy consumption of $46.40 \mathrm{MJ}$ per $\mathrm{kg}$ produced [8] to $67.1 \mathrm{MJ} / \mathrm{kg}$ [11]. 


\section{Methodology}

The LCA has been carried out following the ISO 14040 and ISO 14044 guidelines by modelling the LCI for each of the three different scenarios of cotton cultivation.

\subsection{Goal}

The goal of the study was to quantify the environmental benefits associated with production of organic seed cotton and BCI seed cotton compared to conventional seed cotton production, and also to identify the environmental hotspots over a range of environmental impacts categories. The audience of the study was internal management of Arvind Limited and critical review was not carried out. As such, Arvind Limited does not challenge the results.

\subsection{Scope of the Study}

The typical system under consideration is a cradle-to-gate Life Cycle Inventory including the cultivation of the cotton plant until farm gate. Figure 1 shows the system boundaries considered for the three farming practices under study.

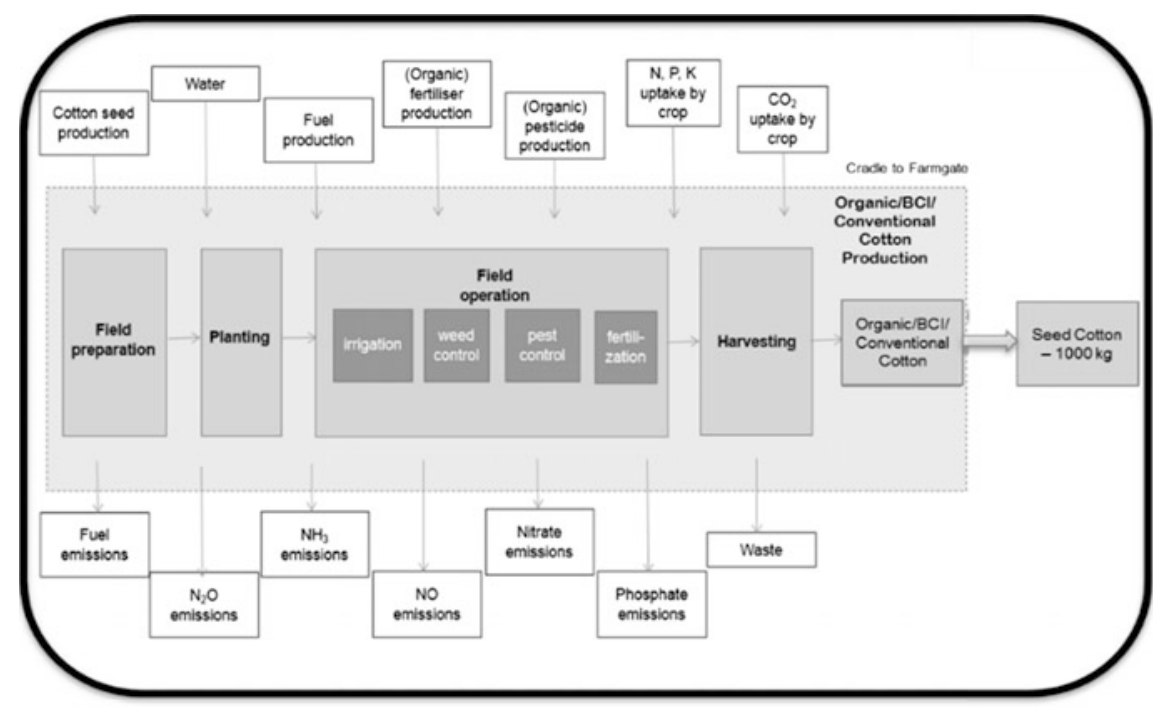

Fig. 1 System boundaries considered in this study 
Cotton cultivation includes four main tasks: field preparation, planting, field operations, and harvesting. Under the collective term field operations: irrigation, weed and pest control, and fertilization are included. These tasks consume energy (electricity and fuel), require inputs (seeds, fertilizers, water etc.) and produce wastes and emissions - all part of the present system.

\subsection{Functional Unit}

The functional unit for this study was 1 ton of seed cotton at the farm gate, for all the three systems, i.e. conventional cotton, BCI cotton and organic cotton production.

\subsection{Data Collection}

Primary data for BCI, organic and conventional cotton cultivation was provided by Arvind Limited for ten representative farming sites. Specifically adapted questionnaires were used to collect inventory data for agricultural systems. These questionnaires were filled in by representatives of producer groups and the data provided were subjected to quality check considering literature references and were compared to other primary cultivation data sources in order to ensure reliable results. The data from each cultivation site were modelled into ten different site specific LCI models and weighted average of those sites were used to create an LCI profile for BCI, Organic and conventional cotton production respectively. Table 1 shows the questionnaires that were used to collect primary inventory data for all three farming practices.

\subsection{Allocation}

During cotton production, two valuable co-products are produced, cotton fibres and cottonseed. Thus, the environmental burden is allocated to both the fibres and the seed. It has been determined that mass-based allocation is the most suitable method to use for this study.

\subsection{Inclusion and Exclusion}

Included in the study are all material and energy flows required for the cultivation phase, as well as all associated wastes and emissions. The study is not limited to 
Table 1 Questionnaires to collect inventory data of organic, BCI cotton and conventional cotton production stages

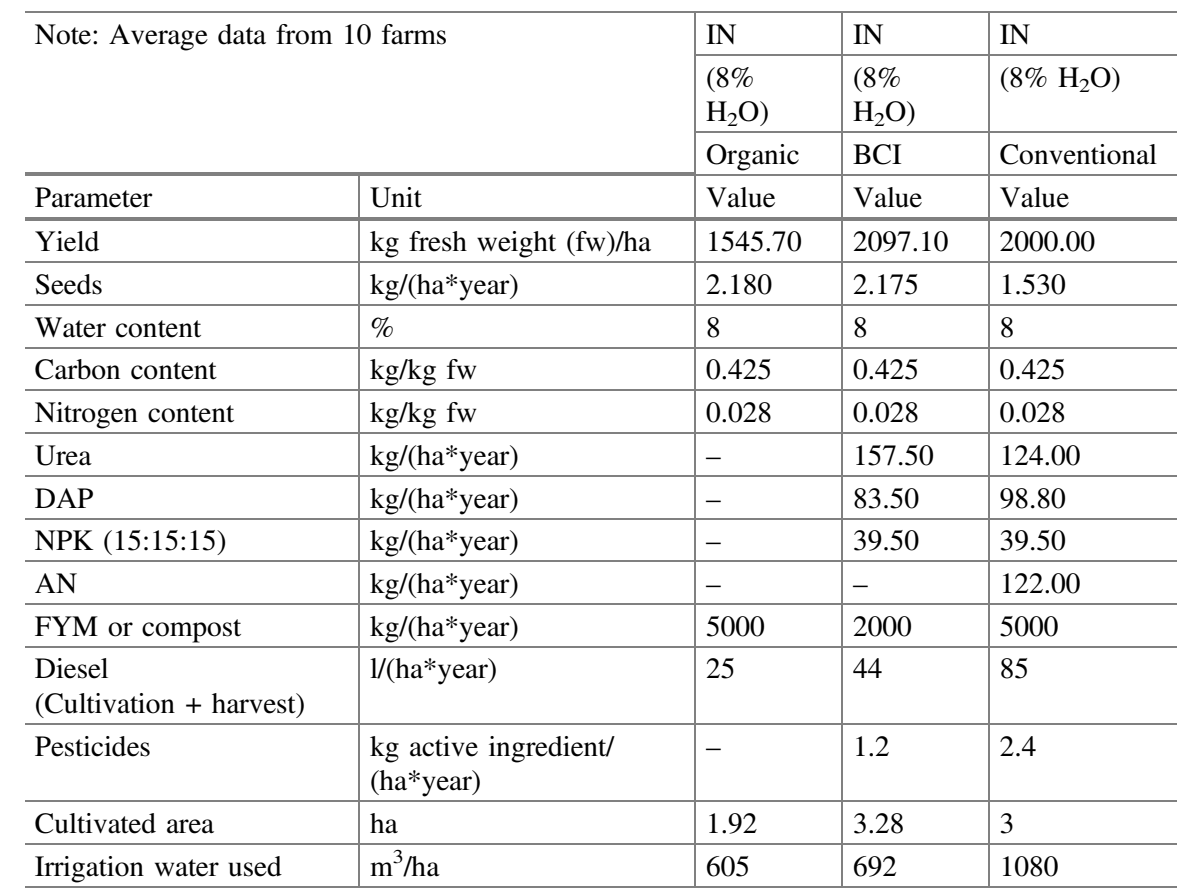

fertilizer and pesticide production but also includes field emissions (e.g. $\mathrm{N}_{2} \mathrm{O}$ ), electricity for pumps and all transports (fertilizer to the field). The provision of infrastructure is not included. The impact of provision of other capital goods such as buildings is also expected to be low, as for example storage takes place at producer groups, so that the scaling effect will result in very low impacts per $\mathrm{kg}$ final product.

\subsection{Software and Database}

The LCA model was created using the GaBi 6.4 Software system for life cycle engineering, developed by thinkstep AG. The associated Gabi database provided the background LCI data in order to characterise several of the raw materials and processes involved in the background system. 


\subsection{Life Cycle Impact Assessment (LCIA)}

The following impacts categories were considered of high relevance: GWP, PED, Acidification Potential (AP), Eutrophication Potential (EP) and Water Consumption (WC). The CML impact assessment methodology was used (Institute of Environmental Sciences of the University of Leiden framework, CML2001, 2013). The impact categories identified above are also considered by Cotton Inc. [8] and Textile Exchange [5].

\section{Modelling Approach-Agriculture Model}

Various factors like the variety of different locations, large number and diversity of farms, variety of agricultural management practices applied, lack of a determined border to the environment, complex and indirect dependence of the output (harvest, emissions) from the input (fertilizers, location conditions, etc.), variable weather conditions within and between different years, and variable pest populations (insects, weeds, disease pathogens, etc.) contribute to the complexity of agricultural modelling. Due to the inherent complications characterizing an agricultural system, a non-linear agrarian calculation model is applied displaying plant production (jointly developed by the LBP of the University of Stuttgart and thinkstep AG). This software model covers a multitude of input data, emission factors and parameters. The agricultural model accounts for the nitrogen cycle in agricultural systems. Specifically, the model includes emissions of nitrate $\left(\mathrm{NO}_{3}{ }^{-}\right)$in water and emissions of nitrous oxide $\left(\mathrm{N}_{2} \mathrm{O}\right)$, nitrogen oxide $(\mathrm{NO})$ and ammonia $\left(\mathrm{NH}_{3}\right)$ into air. The model ensures that emissions from erosion, the reference system (comparable non-cultivated land area) and nutrient transfers within crop rotations are modelled consistently. Carbon-based emissions such as $\mathrm{CH}_{4}, \mathrm{CO}, \mathrm{CO}_{2}$ are considered in foreground and background datasets. Background datasets include emissions resulting from production of fertilizer, pesticides, electricity, and diesel while foreground datasets contain direct emissions such as $\mathrm{CO}_{2}$ due to combustion of fossil fuels by the tractor or irrigation engines and application and decomposition of urea fertilizers in the soil.

\section{Results and Discussion}

Table 2 shows the comparative LCIA results on absolute basis for all three farming practices. It clearly reflects that LCA results of organic cotton is better than BCI cotton and conventional cotton production for all the environmental impacts categories. There has not been significant difference of yield between conventional and BCI cotton production in this study. However, if the yield of BCI cotton increases 
significantly, it will improve their environmental impacts considerably which will bring environmental performances closer to the one from organic cotton. It is anticipated that fertilisers consumption can further be optimised which would further result in mitigation of environmental impacts. Moreover, BCI cotton is a holistic approach to sustainable cotton production which covers all three pillars of sustainability: environmental, social and economic. The system is designed to ensure the exchange of good practices, and to encourage the scaling up of collective action. In case of organic farming, the only additives come in the form of manures, and the soil quality is controlled by crop rotation. The impact on the environment is reduced drastically. Organic farming is best suited for small and marginal farms. Overall, the region of India considered in the study has been battered by multiple droughts and considered amongst the least developed with farmers having poor socio-economic living conditions due to rising cost and declining production yield. With continuous efforts on implementation of BCI initiative and organic cotton farming, Arvind Limited brought around an economic transformation with thousands of farmers, enhancing their farm productivity. The details of environmental performances effects are discussed later in this chapter.

Figure 2 shows the LCIA contribution analysis for all three farming practices.

Acidification Potential (AP): Acidification Potential is calculated in terms of $\mathrm{kg}$ $\mathrm{SO}_{2}$-eq/1 ton of cotton seed. Nitrogen oxide, Sulphur dioxide and Ammonia are the major contributor for this impact category. Ammonia released from field emissions is the highest contributor for the three practices $(7.47 \mathrm{~kg}$ for conventional, $6.93 \mathrm{~kg}$ for BCI and $1.43 \mathrm{~kg}$ for organic cotton). BCI and organic practices shows some advantages compared to conventional cotton $\left(12.14 \mathrm{~kg} \mathrm{SO}_{2}\right.$-eq. for BCI, $3.34 \mathrm{~kg}$ $\mathrm{SO}_{2}$-eq. for organic and $14.06 \mathrm{~kg} \mathrm{SO}_{2}$-eq. for conventional/1 ton of seed cotton), because of reduced field air emissions of ammonia due to elimination of inorganic fertilizers application and less air emissions from tractor operation. Again, the difference is driven by agricultural inputs which are used to a lesser extent in the BCI systems (or not used at all for organic system), i.e. fertilizers and pesticides production, irrigation pumps and tractor operations. Here, the most relevant emissions (sulphur dioxide and nitrous oxides) are caused by power generation and in diesel combustion (transports and machinery use).

Table 2 Comparative analysis of LCIA for organic cotton, conventional cotton versus BCI cotton production (Per 1 ton seed cotton)

\begin{tabular}{l|l|l|l}
\hline Impacts categories & $\begin{array}{l}\text { Organic } \\
\text { cotton }\end{array}$ & $\begin{array}{l}\text { Better Cotton } \\
\text { Initiative } \\
(\mathrm{BCI}) \text { cotton }\end{array}$ & $\begin{array}{l}\text { Conventional } \\
\text { cotton }\end{array}$ \\
\hline Acidification potential $\left[\mathrm{kg} \mathrm{SO}_{2}\right.$-Equiv.] & 3.34 & 12.14 & 14.06 \\
\hline Eutrophication potential $\left[\mathrm{kg} \mathrm{PO}_{4}\right.$-Equiv.] & 0.46 & 2.49 & 7.07 \\
\hline $\begin{array}{l}\text { Global warming potential }(\mathrm{GWP} 100 \\
\text { Years) [kg CO}\end{array}$-Equiv.] & 295 & 435 & 731 \\
\hline Primary energy demand (PED) [MJ] & 1351 & 2510 & 5375 \\
\hline Blue water consumption (WC) $\left[\mathrm{m}^{3}\right]$ & 391.80 & 330.61 & 541.06 \\
\hline
\end{tabular}




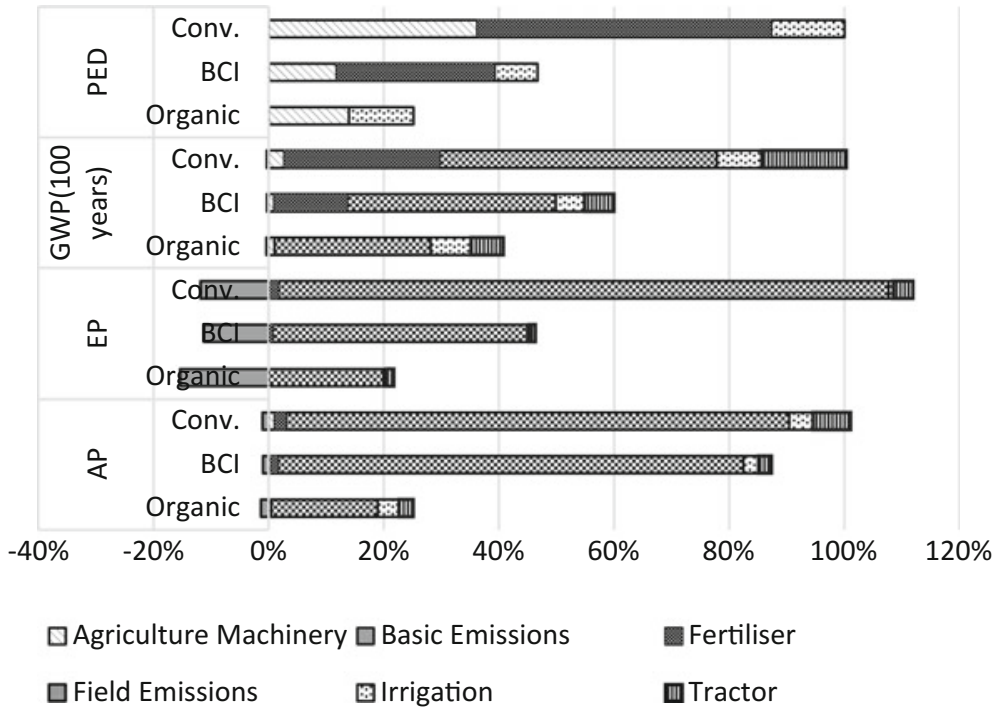

Fig. 2 Comparative analysis of the three cotton cultivation practices

Global Warming Potential (GWP 100 Years): Global Warming Potential is calculated in terms of $\mathrm{kg} \mathrm{CO}_{2}$ eq./1 ton of cotton seed. The combustion of fossil fuel for agricultural machinery, irrigation and other upstream processes are major contributors for GWP. Carbon dioxide emissions are mostly induced by irrigation and agriculture-machinery for all three practices and field emissions are due to $\mathrm{N}_{2} \mathrm{O}$ and $\mathrm{CH}_{4}$. Conventional cotton cultivation depicts the highest among the three practices for carbon dioxide emissions, followed by BCI and organic cultivation. The difference in results is mainly due to the contribution of agricultural inputs, i.e. fertilizer production, provision of pesticides, tractor operations and energy use for irrigation in the conventional system. For all three practices GWP from $\mathrm{N}_{2} \mathrm{O}$ emissions from field is the highest. This is mainly due to the various fertilizers used, water management system and soil use pattern. BCI and organic practices shows some advantages compared to conventional cotton because of reduced field air emissions of Nitrous oxide due to reduction of inorganic fertilizers use, savings of $\mathrm{CO}_{2}$ emissions due to production of less inorganic fertilizers and less $\mathrm{CO}_{2}$ emissions from tractor operation.

Eutrophication Potential (EP): Eutrophication Potential is calculated in terms of $\mathrm{kg} \mathrm{PO}_{4}$ eq./1 ton of cotton seed. Ammonia, nitrogen oxides, nitrous oxide are the major air emissions and nitrate, nitrogen and phosphate are major water emissions resulting in eutrophication potential. Ammonia emissions from field is the highest contributor for BCI and conventional cultivation. This is mainly due to the use of fertilisers in these practices. Nitrogen oxides are major contributors for Organic cultivation. When comparing with the eutrophication potential of all three pro-

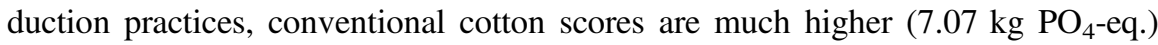


than BCI and Organic which scores $2.40 \mathrm{~kg} \mathrm{PO}$-eq. and $0.46 \mathrm{~kg} \mathrm{PO}_{4}$ eq. respectively. This can be explained by the fact that eutrophication in the BCI as well as conventional system is dominated by soil erosion, and soil erosion data refer to area and are not influenced by production yield. That means that the lower the yield per hectare, the higher the soil erosion per $\mathrm{kg}$ final product. BCI and organic practices shows some advantages compared to conventional cotton in this impact category because of reduced field air emissions of ammonia due to reduction of inorganic fertilizers application.

Primary Energy Demand (PED): PED represents an indicator for fossil resources. Conventional system shows highest PED followed by BCI and organic systems (Conventional-5375 MJ, BCI-2510 MJ and Organic-1351 MJ). BCI and organic practices shows some advantages compared to conventional cotton in this impact category because of savings of energy associated to the production of inorganic fertilizers used in a lower extent, reduced fuel requirement for tractor operation and low fuel requirement for irrigation process.

Water Consumption (WC): Water consumption is smaller for BCI Cotton ( $330 \mathrm{~m}^{3} / 1$ ton of seed cotton) and organic cotton $\left(391 \mathrm{~m}^{3} / 1\right.$ ton of seed cotton) than for the conventional Cotton $\left(541 \mathrm{~m}^{3} / 1\right.$ ton of seed cotton). BCI and organic practices shows some advantages compared to conventional cotton in this impact category because of less irrigation water requirement.

\section{Limitations}

At the level of primary inventory, considering average data over different years would improve their representativeness. Also, increasing the number of farm samples for all the cultivation systems would further enhance the quality and robustness of the inventory data. It is also important to note that for many relevant aspects (such as soil types, nutrient content of soils, soil erosion) primary data were very hard to obtain, there for some of the data proxy values were applied, not necessarily representative of local conditions. An important parameter is also the difference between manual and mechanised farming practices carried out by marginal farmers and rich farmers respectively. Then, Indian geography has different climatic conditions but the study focused only on the western part of the country. Aggregating data into regional averages is an additional challenge and can potentially lead to distortions in a model trying to represent a realistic cultivation system. Finally, some environmental impact routes (biodiversity, carbon sequestration in soils) are difficult to assess in a LCA framework and are not investigated in this study. Hence, some are omitted from the assessment where organic and BCI cotton Cultivation could potentially also show advantages over conventional production systems. 


\section{Conclusion}

To summarize, BCI cotton production system and organic system are extensive cultivation systems that are well adapted to available resources and geographical environment, as well as to existing social and socio-economic conditions. Organic cotton has shown the lowest impacts across all categories assessed, due to non-use of synthetic pesticides and chemical fertilizers, the only additives being manures, and the soil quality being controlled by crop rotation. BCI systems employ good cultivation practices like intercropping and reduce use of mineral fertilizers for cultivation. These systems intend to minimise the harmful impact of crop protection practices, use water efficiently, take care of soil health and conserve natural habitats while preserving the quality of the fibres. Farmers, traders, retailers and consumers, benefit from the economic, social and ecological advantages of responsible cotton projects.

\section{References}

1. < http://www.cotcorp.gov.in/index.aspx> (Accessed 30.04.2017).

2. <https://www.indiaagronet.com/indiaagronet/seeds/organiccottonarticle-seeds.htm> (Accessed 12.04.2017).

3. Cotton Made in Africa and PE International, Life Cycle Assessment of Cotton Made in Africa, Study report, 2014.

4. Textile Exchange and PE International, Life Cycle Assessment of Organic Cotton - A Global average, 2014.

5. <http://bettercotton.org/about-better-cotton/where-is-better-cotton-grown/india/> (Accessed 11.05.2017).

6. International Organization for Standardization, ISO Series 14040 and 14044, Environmental Management - Life Cycle Assessment - Principles and Framework, 2006.

7. Murugesh B.K, Selvadass M, Life Cycle Assessment for Cultivation of Conventional and Organic Seed Cotton fibres, International Journal of Research in Environmental Science and Technology 3(1): 39-45, 2013.

8. Khabbaz B. G, University of Southern Queensland Life Cycle Energy Use and Greenhouse Gas Emissions of Australian Cotton: Impact of Farming Systems, 2010.

9. Barnes E, The Cotton Life Cycle Inventory Project EDWARD BARNES, 2010.

10. Cotton Inc. and PE International, Life Cycle Assessment of Cotton Fibre and Fabric. A Project of the Cotton Foundation and managed by Cotton Incorporated, Cotton Council International and The National Cotton Council. 2012.

11. The Food and Environment Research Agency of UK, The role and business case for existing and emerging fibres in sustainable clothing, 2010. 
Open Access This chapter is licensed under the terms of the Creative Commons Attribution 4.0 International License (http://creativecommons.org/licenses/by/4.0/), which permits use, sharing, adaptation, distribution and reproduction in any medium or format, as long as you give appropriate credit to the original author(s) and the source, provide a link to the Creative Commons license and indicate if changes were made.

The images or other third party material in this chapter are included in the chapter's Creative Commons license, unless indicated otherwise in a credit line to the material. If material is not included in the chapter's Creative Commons license and your intended use is not permitted by statutory regulation or exceeds the permitted use, you will need to obtain permission directly from the copyright holder.

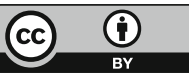

